\title{
THERMOPHILIC FUNGI WITH GLYCOSIDASE AND PROTEOLYTIC ACTIVITIES
}

\author{
N.V. Borzova, O.V. Gudzenko, K.V. Avdiyuk, \\ L.D. Varbanets, L.T. Nakonechna \\ Zabolotny Institute of Microbiology and Virology, NAS of Ukraine, \\ 154 Acad. Zabolotny Str., Kyiv, 03143, Ukraine \\ e-mail:nvb.imv@gmail.com
}

The directed search for extremophilic producers in order to obtain hydrolytic enzymes with increased thermal stability has an unconditional practical potential for use in the food and feed industry to improve the quality of the final product. The aim of the work was to study the ability of collection strains of thermophilic fungi to show $\alpha$-L-rhamnosidase, $\alpha$-galactosidase, cellulase, $\beta$-mannanase, keratinase and caseinolytic activity. Methods. Micromycetes were grown under submerged conditions in test tubes at $42{ }^{\circ} \mathrm{C}$ for 8-14 days. Enzymatic activities were studied in the culture liquid supernatant. p-Nitrophenyl$\alpha$-D-galactopyranoside, naringin, guar gum galactomannan and Na-carboxymethylcellulose were used as substrates to determine $\alpha$-galactosidase, $\alpha$-L-rhamnosidase, $\beta$-mannanase and cellulase activities, respectively. Casein and crushed defatted feathers were served as substrates for the determination of proteolytic activity. Results. The enzymatic activity of 50 strains of micromycetes belonging to 17 species was investigated. The studied group showed high activity: $94 \%$ of the strains had at least one, $34 \%-$ two, $26 \%$ - from three to five enzyme activities. The most active keratinase producers were Thielavia terrestris 1920 and 62, Rhizomucor tauricus 1909, Chrysosporium thermophilum 2050, Thermoascus thermophilus 92 and Thermoascus aurantiacus 2052 (10-26 U/mL). The highest $\alpha$-L-rhamnosidase activity was observed in T. terrestris $62(0.35 \mathrm{U} / \mathrm{mL})$, and carboxymethylcellulase activity -in Thermomyces lanuginosus 2046. Six strains showed $\alpha$-galactosidase (0.05-0.2 U/mL) and four strains - $\beta$-mannanase (5-130 U/mL) activity. Conclusions. As a result new strains producing proteolytic and glycolytic enzymes were isolated among thermophilic micromycetes. Soil thermophilic micromycetes can be used as producers of proteolytic and glycolytic enzymes. Of particular interest are the cultures of Acremonium thermophilum 1963, Corynascus thermophilum 2050, C. sepedonium 1899 and 65068, T. thermophilus 1946, which are capable of producing complexes of proteases and glycosidases in the culture liquid. This indicates that these strains are promising for use as destructors in various technologies processing of complex raw materials.

Keywords: micromycetes, thermophiles, $\alpha$-L-rhamnosidase, $\alpha$-galactosidase, carboxymethylcellulase, $\beta$-mannanase, keratinase, proteolytic activities.

The enormous biotechnological potential of micromycetes in the field of obtaining biologically active compounds is explained by the wide range of their enzymatic activity in relation to various, including hard-to-reach, plant and animal substrates, such as cellulose and hemicellulose, rhamno- and galactoglycosides, collagen and keratin [1].

Polysaccharides, such as cellulose, hemicelluloses and pectin, which constitute up to $70 \%$ of plant biomass, used in many industrial fields, in particular, in biofuel production, pulp and paper production, technologies for improving the quality of food for humans and animal feed $[1,2]$. To process such raw materials, a whole arsenal of polysaccharide-degrading enzymes can be successfully used, belonging to 35 families of glycosylhydrolases, three families of esterases, and six - polysaccharide lyases [3]. The efficiency of raw materials processing depends on the choice of the optimal enzymatic complex to achieve the set goals. The use of $\alpha$-L-rhamnosidases, $\alpha$-galactosidases, cellulases and $\beta$-mannanases in various cycles of polysaccharide processing makes it possible to obtain more active and accessible flavonoids, probiotic oligosaccharides, hydrolyze hard-to-digest galactooligosaccharides, improve the quality of juices and wines, and increase the yield of monosaccharides and digestibility of feed [4-7].

Proteolytic enzymes of microorganisms are among the most demanded enzymes for the 
brewing, food, textile, dairy, pharmaceutical, leather industries, for the production of detergents, as well as for the disposal of difficult-to-degradable waste containing, in particular, keratin. Microbial proteases account a two-thirds share of commercial protease around the globe [8]. Every year, as a byproduct of poultry, livestock, leather industry, a huge amount of keratin-containing waste in the form of feathers, hooves, wool, etc. is thrown into the environment. The waste of chicken feathers alone amounts to about 8.5 million tons, and this amount is increasing every year. But featherdown raw materials contain about $65 \%$ of feed protein (specialized protein - keratin), which can be converted into digestible form by using specific enzymes that can break down mechanically stable keratin proteins. Keratinases can be a cost-effective and environmentally friendly recycling method to combat keratin-containing wastes that pollute the environment [9].

Proteases and keratinases produced by thermophilic micromycetes are of considerable fundamental and practical interest. This is due to the fact that they have the unique ability to survive and synthesize enzymes into the environment at increased temperatures, while minimizing the risk of unwanted contamination of the cultivator during growing. In addition, the thermal stability of such fungal enzymes makes it possible to increase the efficiency of technological processes.

Since the catalytic properties and substrate specificity of hydrolytic enzymes vary significantly within not only different species, but also strains, and biotechnological industries need new high specificity and stable enzymes, the screening for producers among extremophilic, and especially thermophilic, microorganisms remains an urgent task.

The aim of our work was to study the glycosidase ( $\alpha$-L-rhamnosidase, $\alpha$-galactosidase, cellulase, and $\beta$-mannanase) and proteolytic (caseinolytic and keratinase) activities of collection strains of thermophilic fungi.

Materials and methods. The objects of the study were 50 strains of thermophilic micromycetes isolated from various natural and anthropogenic sources (Table 1). The strains are stored in the collection of live cultures of the Department of Physiology and Taxonomy of Micromycetes of the Zabolotny Institute of Microbiology and Virology of the National Academy of Sciences of Ukraine.

Micromycetes were grown for 14 days on wort agar, after which they were grown under submerged conditions on several types of liquid nutrient medium. To detect glycosidase activities, the strains were grown under submerged conditions at a temperature of $42{ }^{\circ} \mathrm{C}$, with a rotation speed of $220 \mathrm{rpm}$ for 8 days on medium of the following composition $(\mathrm{g} / \mathrm{L})$ : maltose (or rhamnose) - 5.0; $\mathrm{KH}_{2} \mathrm{PO}_{4}-1.6 ; \mathrm{MgSO}_{4} \times 7 \mathrm{H}_{2} \mathrm{O}-0.75 ; \mathrm{ZnSO}_{4} \times$ $\times 7 \mathrm{H}_{2} \mathrm{O}-0.25 ;\left(\mathrm{NH}_{4}\right)_{2} \mathrm{SO}_{4}-0.5 ;$ yeast autolysate 0.15 ; soy flour $-10.0 ; \mathrm{pH}$ 5.0. To study keratinase and caseinolytic activities, micromycetes cultures were grown under submerged conditions at $42{ }^{\circ} \mathrm{C}$ for 14 and 8 days on medium of the following composition $(\mathrm{g} / \mathrm{L})$ : crushed defatted feathers - 5.0; sucrose $-13.3 ; \mathrm{NaNO}_{3}-2.0 ; \mathrm{KH}_{2} \mathrm{PO}_{4}-1.0 ; \mathrm{KCl}-$ $0.5 ; \mathrm{MgSO}_{4} \times 7 \mathrm{H}_{2} \mathrm{O}-0.5 ; \mathrm{FeSO}_{4} \times 7 \mathrm{H}_{2} \mathrm{O}-0.01$; $\mathrm{pH} 7.0-7.2$.

After the end of fermentation, the biomass was separated by filtration. Enzyme activities were determined in the culture liquid supernatant. $\alpha$-Galactosidase activity was determined using $p$-nitrophenyl- $\alpha$-D-galactopyranoside ("SigmaAldrich") [10]. $\alpha$-L-Rhamnosidase activity was determined by the Davis method [11] using naringin as a substrate. The unit (U) of enzymatic activity was defined as the amount of the enzyme that hydrolyzes $1 \mu \mathrm{mol}$ of the substrate in $1 \mathrm{~min}$ under the experimental conditions.

$\beta$-Mannanase activity are estimated using $1 \%$ solution of guar gum galactomannan ("SigmaAldrich") as substrate in $0.1 \mathrm{M}$ phosphate citrate buffer, $\mathrm{pH}$ 5.0. The reaction mixture contained $0.25 \mathrm{~mL}$ of supernatant and $0.25 \mathrm{~mL}$ of substrate solution. The reaction mixtures are then incubated at $40{ }^{\circ} \mathrm{C}$ for $30 \mathrm{~min} .2 .5 \mathrm{ml}$ of dinitrosalicylic acid reagent solution was added to the reaction mixture after incubation. The reaction mixtures were then boiled at $100{ }^{\circ} \mathrm{C}$ for $5 \mathrm{~min}$. Absorbance was measured at $540 \mathrm{~nm}$ [12].

Carboxymethylcellulase (CM-cellulase) activity of the strains was determined as described above, but $1 \%$ Na-carboxymethylcellulose 25-75 mPas («Millipore») solution was used as a substrate, and glucose was used as a standard [12].

One unit (U) of CM-cellulase or $\beta$-mannanase activity is the amount of enzyme required to liberate, under the assay conditions, $1 \mu \mathrm{mol} / \mathrm{min}$ reducing sugar expressed as glucose (mannose) equivalent.

Caseinolytic activity was determined by the Anson method as modified by Petrova [13]. The unit of activity was expressed in units that corresponded to the amount of $\mu$ mol of tyrosine released during enzymatic hydrolysis of casein for 1 min under experimental conditions. 
Thermophilic fungi isolated from various sources

\begin{tabular}{|c|c|c|}
\hline No. & Specific name of the strain & Selection source and year \\
\hline 1 & Acremonium thermophilum 1963 & Kyiv region, forest soil, 1998 \\
\hline 2 & Chrysosporium thermophilum & Zhytomyr region, waste wood, 1998 \\
\hline 3 & C. thermophilum 2050 & $\begin{array}{l}\text { Volyn region, soil, } 1998 \\
\end{array}$ \\
\hline 4 & Corynascus sepedonium 65068 & Poltava region, soil, 2001 \\
\hline 5 & C. sepedonium 1899 & Crimea, soil, 1998 \\
\hline 6 & Coprinus delicatus 2053 & Zhytomyr region, compost pit, 1998 \\
\hline 7 & C. delicatus 2007 & Zhytomyr region, compost pit, 1998 \\
\hline 8 & Melanocarpus albomyces 62366 & Sakhalin, wood processing plant, 1998 \\
\hline 9 & M. albomyces 2048 & Kherson region, soil, 1970 \\
\hline 10 & M. albomyces 2056 & Volyn region, soil, 1998 \\
\hline 11 & M. albomyces 1937 & Kyiv, soil, 2002 \\
\hline 12 & M. albomyces F-62164 & Mykolaiv region, soil, 2000 \\
\hline 13 & M. albomyces 2057 & Kremenchuk, refinery, 2007 \\
\hline 14 & Malbranchea cinnamomea 1985 & Kherson, soil, 2002 \\
\hline 15 & Rhizomucor pussillus 1979 & Poltava region, soil, 2000 \\
\hline 16 & Rhizomucor tauricus 1909 & Koktebel, soil, 1998 \\
\hline 17 & R. tauricus 61908 & Mykolaiv region, soil, 2000 \\
\hline 18 & R. tauricus 23 & Mykolaiv region, soil, 2000 \\
\hline 19 & Rhizoтисог miehei 61992 & Kyiv region, rotten grain, 2000 \\
\hline 20 & Scytalidium thermophilum 1911 & Mykolaiv region, soil, 2000 \\
\hline 21 & S. thermophilum 1738 & Mykolaiv region, soil, 2000 \\
\hline 22 & Thielavia terrestris 62 & Mykolaiv region, soil, 2000 \\
\hline 23 & T. terrestris 60 & Mykolaiv region, soil, 2000 \\
\hline 24 & T. terrestris 1920 & Mykolaiv region, soil, 2000 \\
\hline 25 & Talaromyces emersonii 1944 & Ivano-Frankivsk region, forest soil, 2000 \\
\hline 26 & T. emersonii 2043 & Zaporizhzhia, forest soil, 2002 \\
\hline 27 & T. emersonii 143 & Poltava region, pulp pit, 1972 \\
\hline 28 & T. emersonii 2044 & Moldova, sawdust waste, 1996 \\
\hline 29 & Talaromyces thermophilus 2047 & Zaporizhzhia, sawdust waste, 1996 \\
\hline 30 & Thermomyces lanuginosus 1982 & Poltava region, soil, 1998 \\
\hline 31 & T. lanuginosus 2046 & Volyn region, soil, 1996 \\
\hline 32 & T. lanuginosus 2023 & Kherson region, compost pit, 2001 \\
\hline 33 & T. lanuginosus 63298 & Poltava region, soil, 2005 \\
\hline 34 & T. lanuginosus 63299 & Poltava region, soil, 2005 \\
\hline 35 & T. lanuginosus F-63286 & Poltava region, soil, 2005 \\
\hline 36 & T. lanuginosus 2023 & Kherson region, compost pit, 2001 \\
\hline 37 & Thermoascus aurantiacus 2045 & Moldova, soil, 1996 \\
\hline 38 & T. aurantiacus 2049 & Kherson region, compost, 2001 \\
\hline 39 & T. aurantiacus 2051 & Zaporizhzhia, wood working waste, 1996 \\
\hline 40 & T. aurantiacus F-62111 & Mykolaiv region, soil, 2000 \\
\hline 41 & T. aurantiacus 2022 & Mykolaiv region, soil, 2000 \\
\hline 42 & T. aurantiacus 64802 & Mykolaiv region, soil, 1999 \\
\hline 43 & T. aurantiacus 2052 & Poltava region, soil, 2000 \\
\hline 44 & Thermoascus crustaceous $8 \mathrm{~T}$ & Sakhalin, sawdust waste, 2000 \\
\hline 45 & T. crustaceous 65599 & Kyiv region, grain, 2006 \\
\hline 46 & T. crustaceous 65561 & Israel, soil, 2005 \\
\hline 47 & Thermoascus thermophilus 1946 & Sakhalin, pulp and paper mill, 1998 \\
\hline 48 & T. thermophilus 92 & Sakhalin, pulp and paper mill, 2005 \\
\hline 49 & T. thermophilus 91 T Cad & Sakhalin, pulp and paper mill, 2005 \\
\hline 50 & T. thermophilus $89 \mathrm{~T} \mathrm{Cad}$ & Sakhalin, pulp and paper mill, 1998 \\
\hline
\end{tabular}


Keratinase activity was determined using keratin-containing raw materials (crushed defatted feathers) as substrate. The increase in the absorption of the filtrate of the test sample relative to the controls at $280 \mathrm{~nm}$ was taken as the degree of protein release [14]. The unit of keratinase activity was defined as the amount of the enzyme causing an increase in absorption by 0.01 for 3 hours of incubation.

All experiments were replicated 3-5 times. Statistical analysis of the results of the experimental series was carried out by standard methods using Student's t-criterion. The results, presented graphically, were obtained using Microsoft Office Excel 2007.

Results. 50 strains of micromycetes, represented by 17 species of 12 genera, were objects of this research. Most of them were soil representatives, although strains isolated from compost pits, waste from woodworking and pulp and paper enterprises, and oil-contaminated soils have been also investigated.

Some proteolytic and glycosidase activities were studied in the culture liquid of micromycetes. To study the proteolytic activity, the cultures were grown for 14 days. The maximum keratinase activity was observed on the $14^{\text {th }}$ day, and the caseinolytic activity - on the $6-8^{\text {th }}$ day (Fig. 1,2). $68 \%$ of the strains exhibited keratinase activity. The most active were representatives of the species $C$. thermophilum, $R$. tauricus, T. terrestris, T. aurantiacus and T. thermophilus. Keratinase activity was noted in all studied representatives of the species $M$. albomyces and T. thermophilus. In this case, the soil micromycetes were in no way inferior to the crops isolated from industrial sources in terms of the level and the prevalence of activity.

Caseinolytic activity was observed in the culture liquid of only $30 \%$ of the studied strains. However, in all cases it was extremely low. Almost all the strains that showed caseinolytic activity also showed keratinase activity, with the exception of S. thermophilum 1911 and T. lanuginosus 2046.

The studies of glycosidase activities showed that the most common were $\alpha$-L-rhamnosidase and CM-cellulase (31 and 19 strains, respectively) (Fig. 3, 4). The highest $\alpha$-L-rhamnosidase activity was noted in T. terrestris $62(0.35 \mathrm{U} / \mathrm{mL})$, and CM-cellulase activity - in T. lanuginosus 2048 $(16 \mathrm{U} / \mathrm{mL}) . \alpha$-Galactosidase activity was shown by 6 strains $(0.05-0.2 \mathrm{U} / \mathrm{mL})$, and $\beta$-mannanase - by 4 strains $(5-130 \mathrm{U} / \mathrm{mL})$.

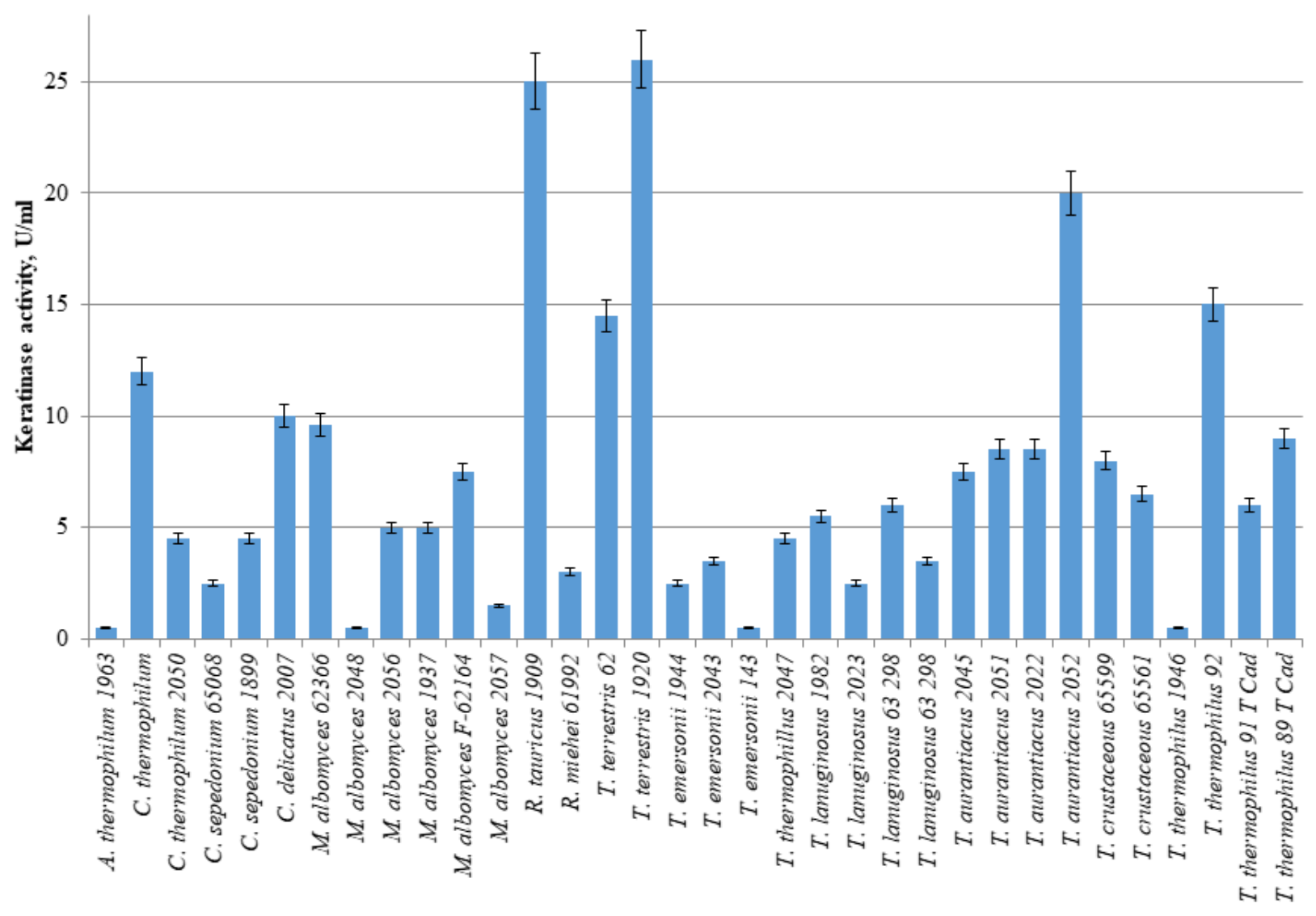

F i g. 1. Keratinase activity of thermophilic fungi on the $14^{\text {th }}$ day of cultivation 


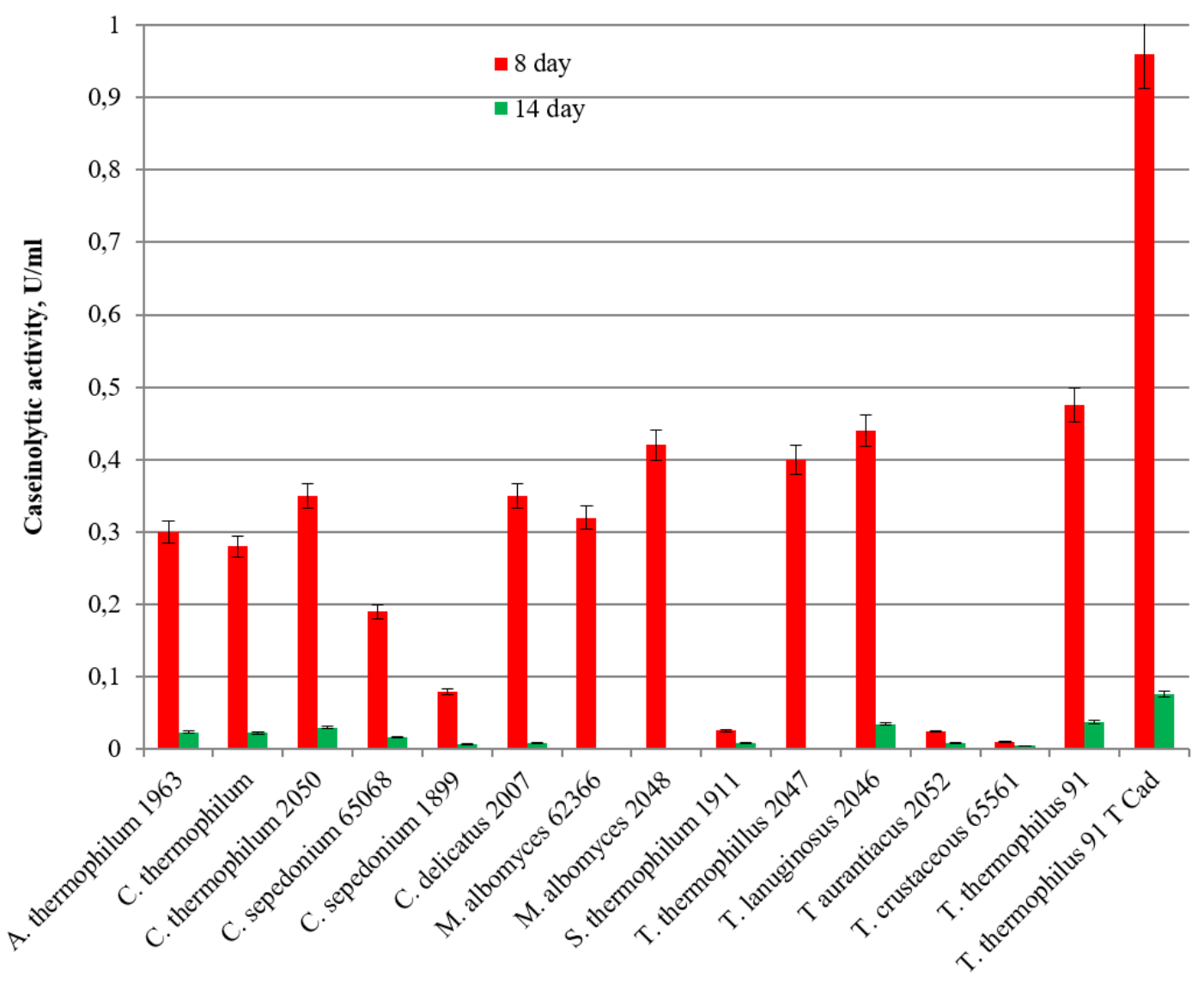

F i g. 2. Caseinolytic activity of thermophilic fungi on the $8^{\text {th }}$ and $14^{\text {th }}$ days of cultivation

In general, the most promising can be noted two strains of the species C. sepedonium, which demonstrated the ability to synthesize all the studied enzymes with high rates of activity and also the representatives of the species $A$. thermophilum, S. thermophilum, T. lanuginosus, T. thermophilus, T. terrestris.

Discussion. The study of extremophiles allows us to discover and recognize more and more ways of adaptation of organisms and proteins, which gives a possibility to approach individualized proteins designed for various stressful conditions. Such protein-enzymes can help in solving many problems, in particular, waste disposal, water purification, and biofuel production $[15,16]$.

Filamentous fungi have great potential in the field of microbial synthesis due to their ability to produce a wide range of hydrolytic enzymes. Glycoside hydrolases and proteases of micromycetes are widely used in areas requiring the transformation of plant cell wall polymers and poorly soluble proteins.

Thermophilic fungi can exist at high temperatures due to the special physiological and biochemical characteristics. Thermostable enzy- mes of fungi are characterized by increased ionic interaction and a stronger hydrophobic core and have advantages over enzymes of mesophilic fungi [15]. Activity of thermophilic enzymes at increased temperatures improves the efficiency of technological processes [8].

Thermophilic fungi represent a taxonomically rather small but widespread group of microscopic fungi. The most studied producers of hydrolytic enzymes among thermophilic and thermotolerant micromycetes are Thermoascus auranticus, T. lanuginosus, Aspergillus flavus, Aspergillus niger, Rhizomucor pusillus, Rhizopus microsporus var. chinensis, Rhizopus schipperae, Achaetomium umbonatum, Chaetomium atrobrunneum, Chaetomium virescens, C. sepedonium, Emericella desertorum, Emericella similis, Rhexothecium globosum, Talaromyces assiutensis, Talaromyces eburneus, Thielavia arenaria, Thielavia expansa, Myceliophthora lutea, Paecilomyces clavisporus, Salilagenidium thermophilum, etc [1, 4, 17-20].

In our work, we studied the glycosidase activity of 50 strains of micromycetes of 17 species from the collection of live cultures of the Department of Physiology and Taxonomy of Micromycetes. The strains were isolated during 1970-2005 years. 


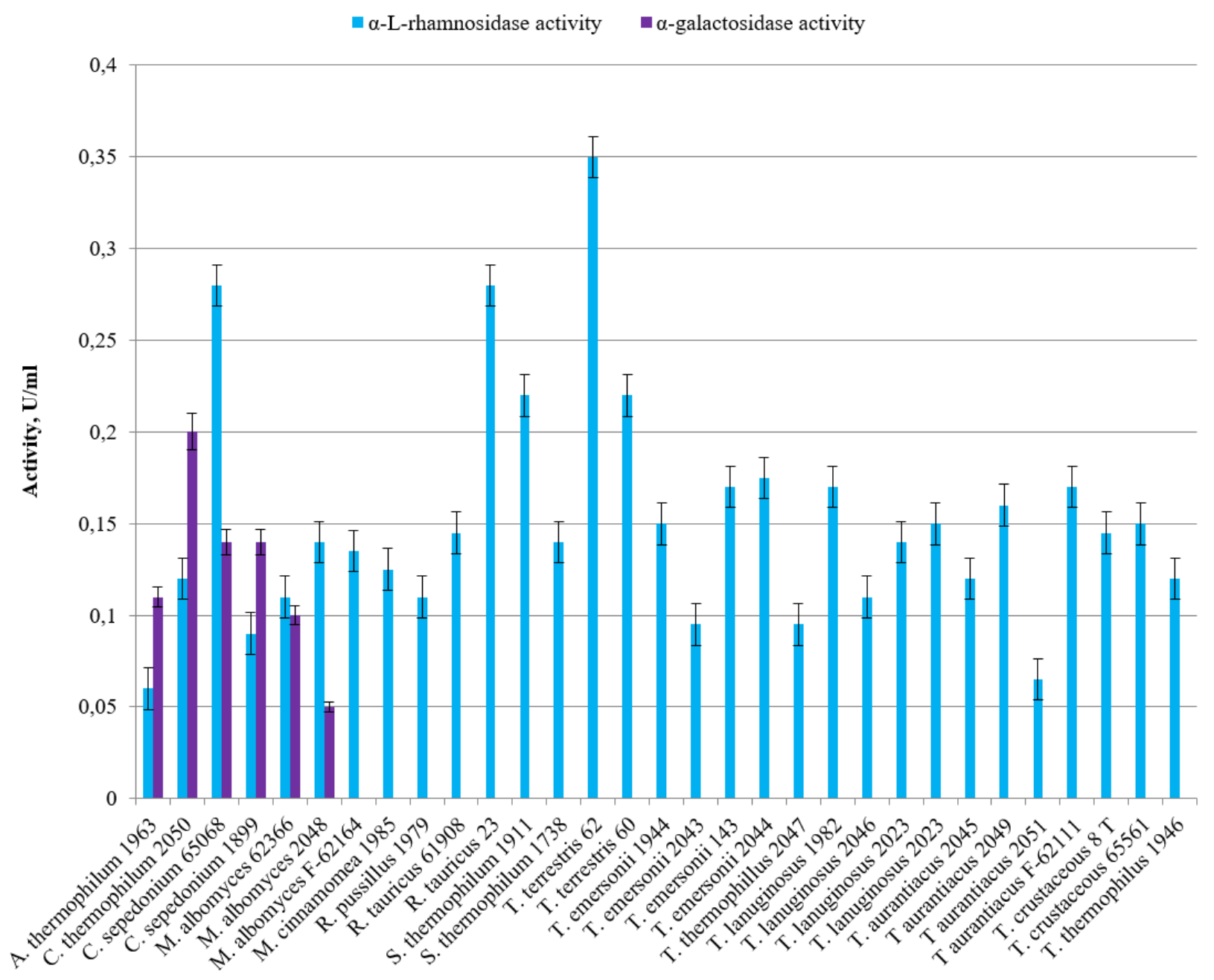

F i g. 3. $\alpha$-Galactosidase and $\alpha$-L-rhamnosidase activities of thermophilic micromycetes (6 days of cultivation, $42^{\circ} \mathrm{C}$ )

Unfortunately, we do not have data on the hydrolase activity of these strains at the time of their isolation, and we cannot assess how long the isolated cultures retain their activity during storage. However, it can be noted that some strains (M. albomyces 2048 and F-62164, C. thermophilum 2050, C. sepedonium $1899, R$. tauricus 1909, T. terrestris 62 and 1920, T. lanuginosus 2046, T. aurantiacus 2052), which were kept in the collection for more than 20 50 years, showed activity at a level above average.

The studied group demonstrated a sufficiently high enzymatic activity: $94 \%$ of the strains showed at least one activity, $34 \%$ - two activities, $26 \%$ - from three to five activities. Most of the strains had keratinase activity (34 strains), followed by $\alpha$-L-rhamnosidase (30 strains), CM-cellulase (19 strains), and caseinolytic (15 strains) activities. And only six and four strains exhibited $\alpha$-galactosidase and $\beta$-mannanase activities, respectively. The widest range of studied activities was observed in strains of the genera Acremonium,
Chrysosporium, Corynascus, Melanocarpus, Thermomyces and Thermoascus, which are common representatives of thermophilic fungi with polysaccharide-degrading activity [19-21]. The most active species were $A$. thermophilum, $C$. sepedonium, $R$. tauricus, $S$. thermophilum, T. lanuginosus, T. thermophilus, T. terrestris, isolated from the soils of various regions of Ukraine and waste of pulp and paper production. Among the representatives of these species, active producers of glycosidases have been described. Thus, T. lanuginosus is widely known for its hydrolytic activity; soil strains of this species are characterized by high activity of xylanases, cellulases, pectinases, $\alpha$-galactosidases [22-24]. Producers of cellulose-degrading enzymes have been described among $S$. thermophilum and $R$. tauricus $[25,26]$. The CM-cellulase activity $(12-16 \mathrm{U} / \mathrm{mL})$ and $\beta$-mannanase activity of C. sepedonium $(130 \mathrm{U} / \mathrm{mL})$ revealed in the culture liquid of $M$. albomyces, C. thermophilum, 


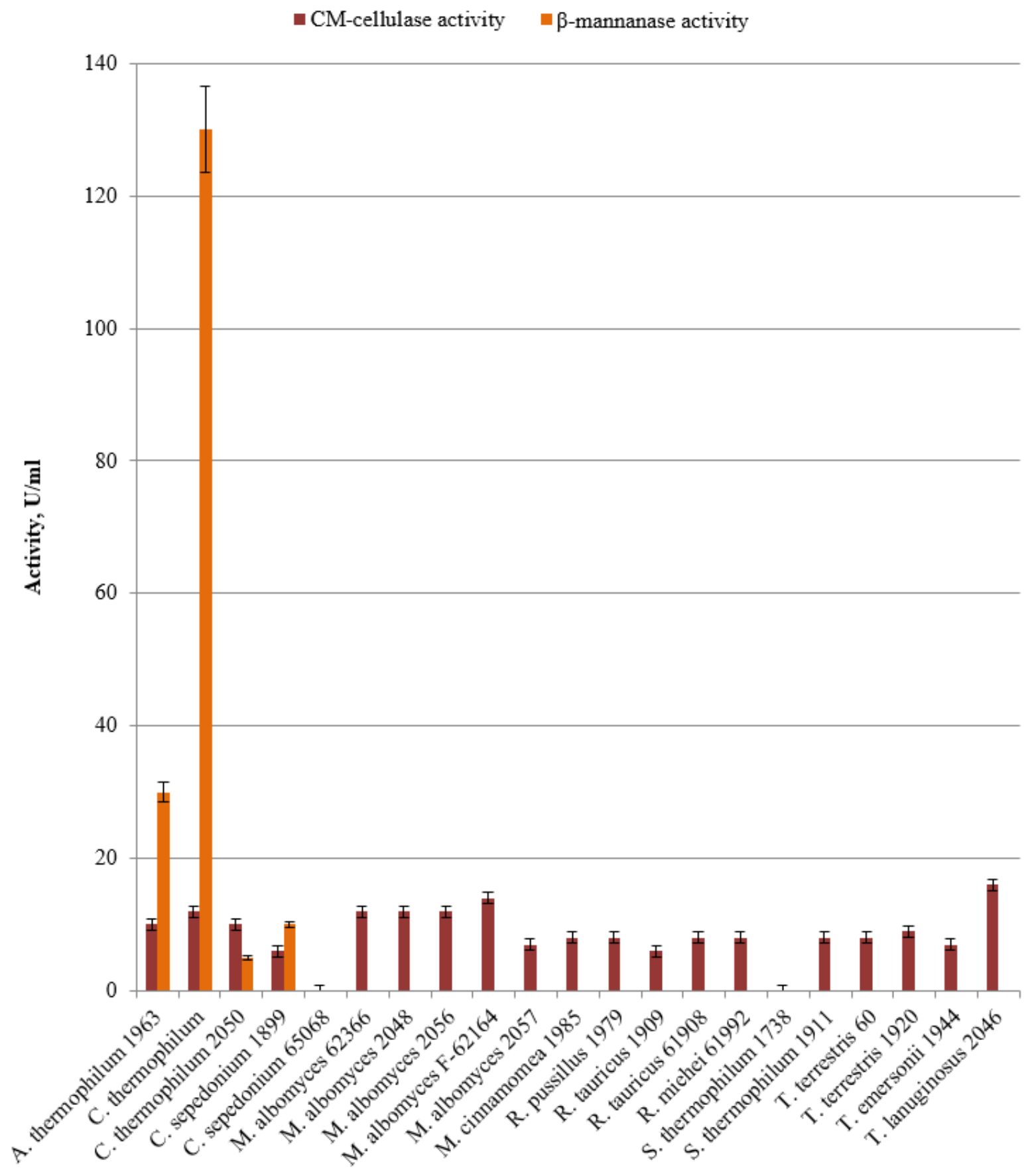

F i g. 4. $\beta$-Mannanase and CM-cellulase activity of thermophilic micromycetes ( 6 days of cultivation, $42^{\circ} \mathrm{C}$ )

T. lanuginosus strains indicate the biotechnological prospects of these fungi. The selection of effective substrates and inductors in the future will help to increase the activity of these strains and compete with such producers as Trichoderma reesei (5-30 U/mL), Pycnoporus coccineus $(111 \mathrm{U} / \mathrm{mL})$, Schizophyllum commune (142 U/mL) [27-29]. $\beta$-Mannanase activity of $C$. sepedonium 1899 and 65068 exceeds the activity of such producers as Penicillium oxalicum GZ-2 (84 U/mL), Aspergillus sojae $(64 \mathrm{U} / \mathrm{mL})$ R. miehei $(105 \mathrm{U} / \mathrm{mL})$, but inferior to T. lanuginosus (354 U/mL) [4].
As a result of screening, we first detected $\alpha$-L-rhamnosidase activity in representatives of A. thermophilum, C. thermophilum, C. sepedonium, $M$. albomyces, M. cinnamomea, $R$. pussillus, $R$. tauricus, S. thermophilum, T. emersonii, T. lanuginosus, T. aurantiacus, T. crustaceous, and $\alpha$-galactosidase - in T. thermophilus. By the level of $\alpha$-L-rhamnosidase activity, the most active strains of $C$. sepedonium, $R$. tauricus and T. terrestris are comparable to such producers as Aspergillus flavipes, Penicillium decumbens, Rhizopus nigricans [30]. 
As for keratinases synthesized by thermophilic fungi, there is very little information in the literature, since most keratinophilic fungi are mesophiles, although Microsporum gypseum and some species of Chrysosporium are thermotolerant and thermophilic. So, optimal keratinase production by Chrysosporium keratinophilum occurs at $90{ }^{\circ} \mathrm{C}[31,32]$. While under optimal conditions, keratinophilic fungi, Scopulariopsis brevicaulis and Trichophyton mentagrophytes [32], result in keratinase activity to the levels 3.2 and $2.7 \mathrm{U} / \mathrm{mL}$ with the ability to degrade 79 and $72.2 \%$ of chicken feathers, respectively. Also, a strain of Aspergillus fumigatus was isolated from decaying wood in a hot spring, which is capable of cleaving chicken feather keratin as the only source of carbon and nitrogen and is known as a producer of several proteinases, such as elastase, fibrinogenolytic protease and collagenase [31]. We first showed keratinase activity for $C$. thermophilum, $C$. delicates, $M$. albomyces, M. cinnamomea, $R$. tauricus, $R$. miehei, S. thermophilum, T. emersonii, T. crustaceous and T. thermophilus species. We have shown a high keratinase activity of $C$. thermophilum, $R$. tauricus, T. thermophilus, T. terrestris, T. auranticus (10-26 U/mL). Strains of these species have repeatedly acted as producers of proteolytic enzymes [16, 17, 33], although they were an order of magnitude inferior activity to representatives of Aspergillus terreus [34]. The high keratinase activity of studied thermophilic fungi testifies to the high potential of this group for the search for producers of keratinolytic enzymes, which are in demand by the processing and feed industry.

As a result of this work, a number of promising new producer strains were selected: $R$. tauricus 1909 and T. terrestris 1920 with high keratinase activity, C. sepedonium 65068, R. tauricus 23 and $T$. terrestris 62 with high $\alpha$-L-rhamnosidase activity, C sepedonium 1899 and 65068 with high $\beta$-mannanase activity, as well as a number of $M$. albomyces and $T$. lanuginosus strains with cellulase activity. It should also be noted that some of the cultures (A. thermophilum 1963, C. thermophilum 2050, C. sepedonium 1899 and 65068, T. thermophilus 1946) produced a complex of protease and glycosidase activities in the culture liquid, which may indicate that these strains are promising for use in technologies for processing raw materials of mixed composition, feed production and waste processing.
Conclusions. As a result among thermophilic micromycetes of new strains producing proteolytic and glycolytic enzymes were isolated. Soil thermophilic micromycetes can be used as producers of proteolytic and glycolytic enzymes. Of particular interest are the cultures of A. thermophilum 1963, C. thermophilum 2050, C. sepedonium 1899 and 65068, T. thermophilus 1946, which are capable of producing complexes of proteases and glycosidases in the culture liquid. This indicates that these strains are promising for use as destructors in various technologies processing of complex raw materials.

\section{ТЕРМОФІЛЬНІ ГРИБИ З ГЛІКОЗИДАЗНОЮ ТА ПРОТЕОЛІТИЧНОЮ АКТИВНІСТЮ}

\section{Н.В. Борзова, О.В. Гудзенко, К.В. Авдіюк, Л.Д. Варбанець, Л.Т.Наконечна}

Інститут мікробіології і вірусології ім. Д.К. Заболотного НАН Украӥни, вул. Академіка Заболотного, 154, Київ, 03143, Украӥна

Резюме

Спрямований пошук екстремофільних продуцентів та отримання шляхом мікробіологічного синтезу гідролітичних ензимів з підвищеною термостабільністю має безумовний практичний інтерес $з$ огляду на їхнє подальше використання у харчовій промисловості для покращення якості кінцевої продукції. Біотехнологічний потенціал термофільних мікроміцетів пов'язаний, насамперед, $з$ широким діапазоном їхньої ензиматичної активності щодо різноманітних важкодоступних субстратів, особливо за підвищених температур. Метою роботи було дослідити здатність музейних термофільних штамів мікроміцетів проявляти $\alpha$-L-рамнозидазну, $\alpha$-галактозидазну, целюлазну, $\beta$-мананазну, кератиназну та казеїнолітичну активність. Методи. Мікроміцети вирощували у пробірках у рідкому поживному середовищі при $42{ }^{\circ} \mathrm{C}$ в умовах перемішування протягом 8-14 днів. Ензиматичні активності досліджували у супернатанті культуральної рідини. Для визначення $\alpha$-галактозидазної активності використовували $n$-нітрофеніл- $\alpha$-Д-галактопіранозид, для $\alpha$-L-рамнозидазної - нарингін, для $\beta$-мананаз ної - галактоманан гуару, для целюлазної - 
Na-карбоксиметилцелюлозу. Для визначення протеолітичних активностей як субстрат використовували казеїн та знежирене куряче пір'я. Результати. Було досліджено ензиматичну активність 50 штамів 17 видів мікроміцетів. Було показано, що ензиматична активність культур не залежала від джерела виділення та часу зберігання. Вивчена група продемонструвала досить високу ензиматичну активність: $94 \%$ штамів виявляли хоча б одну активність, $34 \%-2$ активності, $26 \%$ - від 3-ох до 5-ти активностей. Найбільш поширеною серед вивчених штамів була кератиназна активність (34 штами), далі - $\alpha$-L-рамнозидазна (30 штамів), карбоксиметилцелюлазна (19 штамів) і казеїнолітична (15 штамів) активності. Найактивнішими продуцентами кератинази виявилися Thielavia terrestris 1920 та 62, Rhizomucor tauricus 1909, Chrysosporium thermophilum, Thermoascus thermophilus 92 та Thermoascus aurantiacus 2052 (10-26 од/мл). Найвищу $\alpha$-L-рамнозидазну активність відмічено у T. terrestris 62 (0,35 од/мл), а карбоксиметилцелюлазну - у Thermomyces lanuginosus 2046. $\alpha$-Галактозидазну активність проявили тільки 6 штамів (0,05-0,2 од/мл), а $\beta$-мананазну - 4 штами (5-130 од/мл). В цілому, найбільш активними виявилися 2 штами виду Corynascus sepedonium, які проявили здатність продукувати у культуральну рідину всі досліджені активності. Також на підста-

1. Van den Brink J, de Vries RP. Fungal enzyme sets for plant polysaccharide degradation. Appl Microbiol Biotechnol. 2011; 91(6):1477-1492.

2. Jorgensen H, Vibe-Pedersen J, Larsen J, Felby C. Liquefaction of lignocellulose at high-solids concentrations. Biotechnol Bioeng. 2007; 96(5):862-870.

3. Cantarel BL, Coutinho PM, Rancurel C, Bernard T, Lombard V, Henrissat B. The Carbohydrate-Active EnZymes database (CAZy): an expert resource for glycogenomics. Nucleic Acids Res. 2009; 37:D233-D238. doi: 10.1093/nar/ gkn663.

4. Aulitto, M, Fusco S, Limauro D, Fiorentino G, Bartolucci S, Contursi P. Galactomannan degradation by thermophilic enzymes: a hot topic for biotechnological applications. World J Microbiol Biotechnol. 2019; 35:32. https://doi.org/10.1007/ s11274-019-2591-3. ві отриманих даних перспективними щодо пошуку продуцентів глікозидаз та протеаз можна вважати представників видів Acremonium thermophilum, T. lanuginosus, T. thermophilus, T. terrestris. Висновки. В результаті роботи серед термофільних мікроміцетів було виділено ряд нових штамівпродуцентів протеолітичних та гліколітичних ензимів: R. tauricus 1909 та T. terrestris $1920-3$ високою кератиназною активністю, C. sepedonium $65068, R$. tauricus 23 та T. terrestris 62 - з високою $\alpha$-L-рамнозидазною активністю, C. sepedonium 1899 та 65068 - $з$ високою $\beta$-мананазною активністю, а також ряд штамів Melanocarpus albomyces та T. lanuginosus - 3 карбоксиметилцелюлазною активністю. Особливий інтерес у майбутньому можуть мати культури A. thermophilum 1963, C. thermophilum 2050, C. sepedonium 1899 та 65068, T. thermophilus 1946, які продукують в культуральну рідину комплекс протеаз та глікозидаз, що може свідчити про перспективи використання цих штамів в якості деструкторів в технологіях переробки відходів цілої низки виробництв, обробки сировини змішаного складу для отримання поживних кормів.

Ключові слова: мікроміцети, термофіли, $\alpha$-Lрамнозидазна, $\alpha$-галактозидазна, карбоксиметилцелюлазна, $\beta$-мананазна, кератиназна та казеїнолітична активності.

5. Bhatia S, Singh A, Batra, N, Singh, J. Microbial production and biotechnological applications of $\alpha$-galactosidase. Int J Biol Macromol. 2019. doi:10.1016/j.ijbiomac.2019.10.140Corpus ID: 208217570.

6. Li Y, Liu H, Shi Y, Yan Q, You X, Jiang Z. Preparation, characterization, and prebiotic activity of manno-oligosaccharides produced from cassia gum by a glycoside hydrolase family $134 \beta$-mannanase. Food Chem. 2020; 309:125709.

7. An J, Zhang W, Wu W, Chen G, Liu W. Characterization of a highly stable $\alpha$-galactosidase from thermophilic Rasamsonia emersonii heterologously expressed in a modified Pichia pastoris expression system. Microb Cell Fact. 2019; 18. doi:10.1186/s12934-019-1234-6Corpus ID: 204848821.

8. Razzaq A, Shamsi S, Ali A, Ali Q, Sajjad M, Malik A, Ashraf M. Microbial proteases applica- 
tions. Front Bioeng Biotechnol. 2019; 7:110. doi: 10.3389/fbioe.2019.00110.

9. Vidmar B, Vodovnik M. Microbial keratinases: Enzymes with promising biotechnological applications. Food Technol Biotechnol. 2018; 56(3):312-328. doi:10.17113/ftb.56.03.18.5658

10. Chaplin ME, Kennedy JE. Carbohydrate analysis. Oxford: IRL Press, 1986. 228 p.

11. Davis BJ. Assay of naringinase. Anal Biochem. $1985 ; 149(2): 566-571$.

12. Miller GL. Use of dinitrosalicylic acid reagent for determination of reducing sugars. Anal Chem. $1959 ; 31: 426-428$.

13. Petrova IS, Vintsyunayte MN. [Determination proteolytic activity. Enzyme preparations of microbial origin]. Prikl Biokhim Mikrobiol. 1966; 2(1):322-327. Russian.

14. Nickerson WJ, Noval JJ, Robison RS. Keratinase. I. Properties of the enzyme conjugate elaborated by Streptomyces fradiae. Biochim Biophys Acta. 1963; 77(1):73-86.

15. Brininger C, Spradlin S, Cobani L, Evilia C. The more adaptive to change, the more likely you are to survive: Protein adaptation in extremophiles. Semin Cell Dev Biol. 2018; 84:158-169.

16. Macchione MM, Merheb CW, Gomes E, da Silva R. Protease production by different thermophilic fungi. Appl Biochem Biotechnol. 2008; 146:223-230.

17. Merheb-Dini C, Cabral H, Leite RS, Zanphorlin LM, Okamoto DN, Rodriguez GO, Juliano L, Arantes EC, Gomes E, da Silva R. Biochemical and functional characterization of a metalloprotease from the thermophilic fungus Thermoascus aurantiacus. J Agric Food Chem. 2009; 57(19):9210-9217.

18. Mouchacca J. Heat tolerant fungi and applied research: Addition to the previously treated group of strictly thermotolerant species. World J Microbiol Biotechnol. 2007; 23(12): 1755-1770.

19. Escuder-Rodriguez JJ, DeCastro ME, Cerdan ME, Rodriguez-Belmonte E, Becerra M, Gonzalez-Siso MI. Cellulases from thermophiles found by metagenomics. Microorganisms. 2018; 6(3):66.

20. Patel AK, Singhania RR, Sim SJ, Pandey A. Thermostable cellulases: Current status and per- spectives. Bioresour Technol. 2019; 279:385392.

21. Miettinen-Oinonen A, Londesborough J, Joutsjoki V, Lantto R, Vehmaanpera J. Three cellulases from Melanocarpus albomyces for textile treatment at neutral pH. Enzyme Microb Technol. 2004; 34:332-341.

22. Berlemont R. Distribution and diversity of enzymes for polysaccharide degradation in fungi. Sci Rep. 2017; 7:222. https://doi.org/10.1038/ s41598-017-00258-w.

23. Aulitto M, Fusco S, Limauro D, Fiorentino G, Bartolucci S, Contursi P. Galactomannan degradation by thermophilic enzymes: a hot topic for biotechnological applications. World J Microbiol Biotechnol. 2019; 35:32.

24. Rezessy-Szabo JM, Nguyen QD, Hoschke A, Braet C, Hajos G, Claeyssens M. A novel thermostable alpha-galactosidase from the thermophilic fungus Thermomyces lanuginosus CBS 395.62/b: purification and characterization. Biochim Biophys Acta. 2007; 1770(1):55-62. doi: 10.1016/j.bbagen.2006.06.022.

25. Zanoelo FF, Polizeli M, Terenzi HF, Jorge JA. $\beta$-Glucosidase activity from the thermophilic fungus Scytalidium thermophilum is stimulated by glucose and xylose. FEMS Microbiol Letters. 2004; 240(2):137-143.

26. de Cassia PJ, Paganini MMN, Rodrigues A, Brito de Oliveira T, Boscolo M, da Silva R, Gomes E, Bocchini Martins DA. Thermophilic fungi as new sources for production of cellulases and $x y$ lanases with potential use in sugarcane bagasse saccharification. J Appl Microbiol. 2015; 118(4): 928-939.

27. Liu P, Lin A, Zhang G, Zhang J, Chen Y, Shen T, Zhao J, Wei D, Wang W. Enhancement of cellulase production in Trichoderma reesei RUT-C30 by comparative genomic screening. Microb Cell Fact. 2019; 18:81. https://doi.org/10.1186/ s12934-019-1131-z.

28. Elisashvili V, Kachlishvili E, Penninckx M. Effect of growth substrate, method of fermentation, and nitrogen source on lignocellulose-degrading enzymes production by white-rot basidiomycetes. J Ind Microbiol Biotechnol. 2008; 35(11):1531-1538. doi: 10.1007/s10295-008- 
0454-2.

29. Metreveli E, Kachlishvili E, Singer SW, Elisashvili V. Alteration of white-rot basidiomycetes cellulase and xylanase activities in the submerged co-cultivation and optimization of enzyme production by Irpex lacteus and Schizophyllum commune. Bioresour Technol. 2017; 241:652-660.

30. Eliades LA, Rojas NL, Cabello MN, Voget CE, Saparrat MC. $\alpha$-L-Rhamnosidase and $\beta$-D-glucosidase activities in fungal strains isolated from alkaline soils and their potential in naringin hydrolysis. J Basic Microbiol. 2011; 51:659-665.

31. Santos R, Firmino AAP, de Sa CM, Felix CR. Keratinolytic activity of Aspergillus fumigatus Fresenius. Curr Microbiol. 1996; 33(6):364-370.
32. Gopinath SC, Anbu P, Lakshmipriya T, Tang TH, Chen Y, Hashim U, Arshad MK. Biotechnological aspects and perspective of microbial keratinase production. BioMed Res Int. 2015; article ID 140726, 10. doi: 10.1155/2015/140726.

33. Merheb CW, Cabral H, Gomes E, Da-Silva. Partial characterization of protease from a thermophilic fungus, Thermoascus aurantiacus, and its hydrolytic activity on bovine casein. Food Chem. 2007; 104(1):127-131.

34. Osman ME, Khattab OH, Elsaba YM. Aspergillus terreus proteases: characterization and applications. J Chem Biol Phys Sci. 2014; 4(3):23332346.

Received 11.01.2021 